\title{
Growth hormone treatment of osteoporotic postmenopausal women - a one-year placebo-controlled study
}

\author{
Maria Sääf, Agneta Hilding, Marja Thorén, Staffan Troell ${ }^{1}$ and Kerstin Hall \\ Department of Endocrinology and Diabetology and ${ }^{1}$ Department of Diagnostic Radiology, Karolinska Institute and Hospital, Stockholm, Sweden \\ (Correspondence should be addressed to M Sääf, Department of Endocrinology and Diabetology, Karolinska Hospital, S-17176 Stockholm, Sweden)
}

\begin{abstract}
Objectives: To study the effect of 12 months of growth hormone (GH) treatment on bone markers, bone mineral density (BMD), lean body mass (LBM) and body fat mass (BF) in postmenopausal osteoporotic women.

Design: Sixteen patients were randomised to a double-blind randomised placebo-controlled one-year study with daily s.c. injections of GH or placebo. After the first year 14 patients ( 8 placebo treated, $6 \mathrm{GH}$ treated) were recruited to $\mathrm{GH}$ treatment during the second year. All patients were also supplemented with $0.5 \mathrm{~g}$ calcium per oral.

Methods: Bone mineral density and body composition were assessed by dual energy X-ray absorptiometry. Biochemical bone markers were analysed by RIA or HPLC techniques. Diurnal GH profiles were performed with continuous venous blood sampling.

Results: Sixteen patients started in the placebo-controlled study. In all, twelve patients completed one year and only four patients completed two years of GH treatment. At baseline 3 patients had serum insulin-like growth factor-I (S-IGF-I) levels below -2 s.D. for age. Maximal diurnal GH levels tended to correlate negatively with S-IGF-I $(P=0.076)$. S-IGF-I was unrelated to BMD. Serum IGF-binding protein-1 (S-IGFBP-1) correlated negatively with femoral neck BMD $(r=-0.61, P=0.012)$. The intended $\mathrm{GH}$ dose of $0.05 \mathrm{U} / \mathrm{kg} /$ day or a maximum of $3 \mathrm{U} /$ day s.c. was reduced to $0.024 \pm 0.004 \mathrm{U} / \mathrm{kg} /$ day, equal to 0.5-2.7 U/day due to frequent side effects, and four patients were excluded. After one year of GH treatment BF increased slightly, LBM and BMD in total body and lumbar spine were unchanged but femoral neck BMD had decreased $3.4 \pm 1.6 \%(P<0.05)$. The mean S-IGF-I increase was 32\% (range $-38-138 \%)$. Mean levels of the bone formation markers S-osteocalcin and S-procollagen type I propeptide increased maximally by 88 and 36\% respectively after 9-12 months while the bone resorption markers were unchanged. In the placebo-treated group there were no significant alterations. Conclusions: The effects on S-IGF-I, bone markers and LBM were small although GH-related side effects were common. The reason for this apparent partial resistance to the anabolic effects of GH is not clear but nutritional deficits may be involved. Assessment of the effects of GH on bone mass and fracture rate requires longer study periods than one year.
\end{abstract}

European Journal of Endocrinology 140 390-399

\section{Introduction}

Growth hormone $(\mathrm{GH})$ is essential for growth and maintenance of bone tissue. During childhood and adolescence GH is necessary for linear growth (1). Adult onset $\mathrm{GH}$ deficiency (GHD) is associated with a lower bone mass, at least in women $(2,3)$, and increased frequency of osteoporotic fractures has been reported among GHD patients (4). Bone mass increases after $12-$ 18 months when GHD adults are treated with daily $\mathrm{GH}$ supplementation $(2,3)$. Less is known about the effect of $\mathrm{GH}$ on bone mass and body composition in normal or osteoporotic elderly people (5). GH secretion and GHdependent serum insulin-like growth factor-I (IGF-I) levels diminish with increasing age $(6,7)$. Subnormal serum IGF-I levels have been reported in men and women with osteoporosis $(8-10)$.
The effect of IGF-I is modulated by six different IGF binding proteins (IGFBP-1 to -6). $\mathrm{GH}$ is one of the important regulators of IGFBP-3 production. Serum IGFBP-3 levels have been found to be lower in middleaged women and men with osteoporosis than in agematched controls $(9,11)$. IGFBP-1 is produced in the liver, is suppressed by insulin and is considered to be a factor which regulates short-term bioavailability of free IGF-I. As yet there have been no reports concerning IGFBP-1 in patients with osteoporosis.

A few attempts have been made to increase IGF-I by long term GH treatment and evaluation of its effect on bone metabolism in elderly women, but the results have been conflicting. One of the first studies on osteoporosis was published by Aloia et al. (12) who demonstrated decreased back pain but a drop in radial bone density after one year of GH treatment (2-6 U/day). Two recent 
studies have addressed the effect of long term sequential GH treatment of postmenopausal women with low bone mass. $\mathrm{GH}$ administration to osteopenic elderly women for 12/56 days increased bone turnover and caused small increases of bone mass in the lumbar spine and total hip after two years (13). When osteoporotic postmenopausal women were treated with sequential GH for 7 days/3 months during 2 years femoral shaft bone mineral density (BMD) decreased compared with baseline values (14). Bone mass increased slightly in spine and distal radius only when $\mathrm{GH}$ was administered together with calcitonin.

The aim of the present study was to evaluate, in a placebo-controlled, one-year study, whether GH given in daily doses equivalent to those given to adult GHD patients could improve BMD and body composition in postmenopausal women with manifest osteoporosis and, in addition, to relate changes in BMD to serum IGF-I responses.

\section{Subjects and methods}

\section{Study population}

Sixteen patients aged 58 to 74 years were consecutively recruited among women who were at least 5 years postmenopausal and had been referred to the osteoporosis unit due to low-energy trauma fractures. Inclusion criteria were bone mineral density below $1 \mathrm{~g} / \mathrm{cm}^{2}$ in the ultradistal part of the radius and radiological presence of one to four vertebral body compression fractures defined as a vertebral body height loss of $>15 \%$ at the anterior, middle or posterior margin. One patient with bilateral wrist fractures was included based on hip BMD below -2.5 s.D. of the mean for young healthy subjects, as her wrists could not be adequately measured. Patients with secondary osteoporosis caused by disease or medication or with other metabolic bone diseases, except for osteoarthritis, were excluded. In addition patients with diabetes mellitus and other significant diseases were excluded.

Before entering the study the mean height loss was $5.8 \pm 0.8 \mathrm{~cm}$ as judged by reported maximal height and measured present height. Mean body mass index (BMI) was 24.6, but considering the reported height loss the BMI corresponded to about 22. Two women had previous hip fractures, one a shoulder fracture and seven women had earlier wrist fractures. Six patients had multiple vertebral compression fractures. None of the patients had been treated with bone active drugs, including medium potent oestrogens, other than calcium and prescription-free multivitamin tablets.

At varying times (median 9 days) before entering the present study, diurnal profiles of $\mathrm{GH}$ were determined in samples collected every $20 \mathrm{~min}$ throughout $24 \mathrm{~h}$ using the continuous withdrawal technique in 15 of the patients (15).

\section{Study protocol}

Sixteen patients were randomised to a double blind schedule with either placebo or GH injected s.c. daily at 2000-2200 h during one year followed by one year of $\mathrm{GH}$ treatment offered to all participants. The patients treated with placebo during the first year and GH during the second year comprise the placebo/GH group and those treated with $\mathrm{GH}$ from the start of the study comprise the GH/GH group. Due to adverse effects only six patients in the placebo/GH group and six patients in the $\mathrm{GH} / \mathrm{GH}$ group completed one year of GH therapy. The six patients in the $\mathrm{GH} / \mathrm{GH}$ group started $\mathrm{GH}$ treatment for a second year but only four of them pursued the whole period. GH (Genotropin, Pharmacia \& Upjohn, Stockholm, Sweden) in successively increasing doses from 0.02 to $0.05 \mathrm{U} / \mathrm{kg} /$ day, maximum $3 \mathrm{U} /$ day, were titrated according to a pre-set schedule and modified due to the individual subjective tolerance of the patients. In only one case was dose reduction carried out during the placebo period. The mean GH dose administered between the start of the study and 12 months was $1.5 \pm 0.3 \mathrm{U} /$ day (ranging from 0.9 to $2.7 \mathrm{U} /$ day) in the $\mathrm{GH} / \mathrm{GH}$ group vs $1.1 \pm 0.2 \mathrm{U} /$ day (ranging from 0.5 to $1.6 \mathrm{U} /$ day) in the placebo/GH group, or when corrected for body weight (BW) $0.026 \pm$ 0.005 and $0.018 \pm 0.003 \mathrm{U} /$ day $/ \mathrm{kg} \mathrm{BW}$ respectively (not significantly different). Compliance was checked by measuring the volume of injection solution consumed. All patients were given $0.5 \mathrm{~g}$ calcium/day per oral during the study.

Before the study the patients had been informed about possible side-effects. During the first year they were asked to report any change of well-being at each visit. During the second year the patients were specifically asked about fluid retention symptoms which might have yielded more complaints during the latter half of the study.

The study was performed in an out-patient setting with follow-up after 1 week, 1, 3, 6, 9 and 12 months during each treatment period. Blood and urine samples were collected at each visit. Laboratory measurements to ensure no ill-effects of treatment, including blood glucose, were performed at every visit. Analyses of markers of GH therapy, such as IGF-I, were not performed until the end of the study. Bone densitometry and body composition were measured every six months. Radiological evaluation of the thoracic and lumbar spine was carried out before and after the study period.

The study protocol was approved by the Committee for Medical Ethics of the Karolinska Hospital and the Swedish Medical Product Agency.

\section{Measurement of bone mineral density}

Dual energy X-ray absorptiometry (DXA, Lunar DPX-L, Lunar Corp-1, Madison WI, USA) was used for measuring BMD of whole body, lumbar spine and hip 
(16) and expressed as areal bone mineral mass $\left(\mathrm{g} / \mathrm{cm}^{2}\right)$, percentage change from the age-matched and young adult mean and also standard deviations from the latter (T-score). Bone mineral density was measured in forearm by single photon absorptiometry (SPA) (17) before entry to the study.

Radiological evaluation was carried out by an experienced radiologist using manual evaluation of individual vertebral body measures. Progression of vertebral compression fractures was inferred when these heights were decreased by at least a further $3 \mathrm{~mm}$.

\section{Measurement of body composition}

Estimates of body composition (lean body mass (LBM), body fat mass (BF) and bone mineral content (BMC)) were acquired from whole body DXA measurements. Total body water (TBW) was measured with bioelectrical impedance (Akern LJR, Florence, Italy) using a two-compartment model provided by the manufacturer. Standing body height was registered with a Harpenden stadiometer.

\section{Assays}

IGF-I was determined in serum by RIA after separation of IGFs from IGFBPs by acid-ethanol extraction and cryoprecipitation. To minimize interaction of IGFBPs, des(1-3)-IGF-I was used as the ligand (18). The detection limit was $8 \mu \mathrm{g} / \mathrm{l}$. Including the extraction step, the intra- and interassay coefficients of variation were $4.0 \%$ and $11 \%$ respectively. The IGF-I values are age dependent, declining with age. The normal range of IGF-I was determined in serum from 448 healthy subjects aged 20 to 96 years, an extended material base compared with that previously described (19). Thus, the geometrical mean concentration at 20 years of age was $277 \mu \mathrm{g} / \mathrm{l}$ with a range of $159-481 \mu \mathrm{g} / \mathrm{l}$ ( \pm 2 s.D.), and at 90 years of age the mean was $91 \mu \mathrm{g} / \mathrm{l}$ with a range of $52-158 \mu \mathrm{g} / \mathrm{l}$. IGF-I values were also expressed as S.D. scores calculated from the regression line of the values in these 448 healthy subjects.

Serum concentrations of IGFBP-1 were determined according to the method of Póvoa et al. (20). The sensitivity of the RIA was $3 \mu \mathrm{g} / \mathrm{l}$ and the intra- and interassay coefficients of variation were $3 \%$ and $10 \%$ respectively. The geometrical mean and range of IGFBP-1 were 34 and $12-91 \mu \mathrm{g} / \mathrm{l}$ respectively in healthy subjects aged 20-66 years (21).

Serum levels of IGFBP-3 were analysed using an immunoradiometric assay kit (DSL-6600 IGFBP-3 IRMA, DSL Inc., Webster, TX, USA). The reference range (mean \pm 2 s.D.) for healthy subjects aged 50-70 years was $2966 \pm 878 \mu \mathrm{g} / \mathrm{l}$.

Plasma GH was analysed using a sensitive kit (DELFIA, Wallac, Turku, Finland) with a detection limit of $0.04 \mu \mathrm{g} / \mathrm{l}$. Serum insulin was determined using an RIA kit (Pharmacia AB, Uppsala, Sweden). Mean fasting level for healthy individuals was $<144 \mathrm{pmol} / \mathrm{l}$.

Serum levels of carboxyterminal propeptide of type I procollagen (PICP) were analysed using an RIA kit (Orion Diagnostica, Oulunsalo, Finland), having a reference interval in healthy women ranging from 50 to $170 \mu \mathrm{g} / \mathrm{l}$ (mean \pm 2 s.D.). The determination of the $\mathrm{N}-$ terminal propeptide of type III collagen (PIIINP) was performed by an RIA-gnost kit (CIS Bio International, Gif-sur-Yvette, France), with a reference interval in healthy subjects of 300-800 U/l. Serum levels of osteocalcin were determined using an immunoradiometric assay (ELSA-OSTEO, CIS Bio International). The mean and normal range in women, aged 61-70 years, were 24.4 and 12.9-55.9 $\mu \mathrm{g} / \mathrm{l}$. 1,25-Dihydroxyvitamin $\mathrm{D}_{3}$, calcitriol, in serum was measured by an RIA (Nichols Institute, Boldon, UK) and the reference range was $10-60 \mathrm{ng} / \mathrm{l}$.

Serum total alkaline phosphatase activity (ALP), phosphate and urea as well as urine calcium were measured by colorimetric methods using a Kodak Ektachem 700 and 250 Analyser (Eastman Kodak, Rochester, NY, USA). The reference intervals were: $<4.6 \mu \mathrm{kat} / \mathrm{l}$ for ALP, $0.6-1.6 \mathrm{mmol} / \mathrm{l}$ for phosphate, $3.0-8.0 \mathrm{mmol} / \mathrm{l}$ for urea, $3.0-6.0 \mathrm{mmol} / \mathrm{l}$ for glucose and $1.0-7.0 \mathrm{mmol} / \mathrm{l}$ for urinary calcium. Hydroxyproline in urine was determined by an HPLC method (22) and values in healthy subjects ranged from 80$270 \mu \mathrm{mol} / \mathrm{l}$.

\section{Statistical analysis}

Results are presented as means \pm s.E.M., unless otherwise stated. The comparability of the two groups, i.e. the placebo/GH and the $\mathrm{GH} / \mathrm{GH}$ group, at baseline was assessed by unpaired $t$-test. One-way repeated measures ANOVA or Friedman's repeated measures ANOVA on ranks, followed by Dunnett's test, was employed to evaluate treatment effects compared with baseline on variables with normal or non-normal distribution respectively. Comparisons of treatments, placebo vs $\mathrm{GH}$, over time were made by two-way repeated measures ANOVA. Correlations between variables were assessed using least square linear regression analysis. The value of acceptance for statistical significance was set at $P<0.05$. Statistical analyses were performed using Sigma Stat for Windows (Jandel Scientific GmbH, Erkarth, Germany).

\section{Results}

\section{Basal conditions}

Baseline characteristics of the whole material are summarised in Table 1. Only 12 of 16 patients completed at least one year with active GH treatment; six of these patients started the study with a placebo period, placebo/GH group, while six patients were 
Table 1 Characteristics of the patient material at the start of the study. Values are means \pm S.E.M. with the range in parentheses.

\begin{tabular}{|c|c|c|c|}
\hline & \multirow[b]{2}{*}{$\begin{array}{l}\text { Patients included in the study } \\
\qquad(n=16)\end{array}$} & \multicolumn{2}{|c|}{ Patients completing the study $(n=12)$} \\
\hline & & $\begin{array}{l}\text { Placebo/GH group } \\
\qquad(n=6)\end{array}$ & $\begin{array}{l}\mathrm{GH} / \mathrm{GH} \text { group } \\
(n=6)\end{array}$ \\
\hline $\begin{array}{l}\text { Age (years) } \\
\text { Weight }(\mathrm{kg}) \\
\text { Height, present }(\mathrm{cm}) \\
\text { BMl, present }\left(\mathrm{kg} / \mathrm{m}^{2}\right) \\
\text { Height loss } \\
\text { LBM }(\mathrm{kg}) \\
\text { TBW }(\mathrm{kg}) \\
\text { BF }(\mathrm{kg})\end{array}$ & $\begin{aligned} 67.8 & \pm 1.1(60-74) \\
62.3 & \pm 2.1(48.6-81.8) \\
159.2 & \pm 1.2(150.1-166.3) \\
24.6 & \pm 0.8(20.2-33.2) \\
-5.8 & \pm 0.8(-12.5-0.0) \\
37.4 & \pm 1.0(31.3-46.3) \\
30.0 & \pm 0.5(26.7-34.6) \\
22.3 & \pm 1.5(11.4-34.6)\end{aligned}$ & $\begin{array}{r}66.7 \pm 1.5 \\
66.0 \pm 4.5 \\
159.6 \pm 2.6 \\
26.0 \pm 1.9 \\
-6.3 \pm 1.8 \\
38.5 \pm 2.0 \\
30.2 \pm 1.0 \\
25.0 \pm 2.8\end{array}$ & $\begin{array}{r}67.3 \pm 2.4 \\
58.8 \pm 2.9 \\
160.2 \pm 1.5 \\
22.9 \pm 1.1 \\
-5.1 \pm 1.3 \\
36.5 \pm 0.7 \\
29.7 \pm 0.5 \\
19.9 \pm 2.5\end{array}$ \\
\hline $\begin{array}{l}\text { BMC }(\mathrm{kg}) \text { total body } \\
\text { BMD }\left(\mathrm{g} / \mathrm{cm}^{2}\right) \text { ultra distal forearm } \\
\text { BMD }(\% \text { of age-matched })\end{array}$ & $\begin{array}{c}1.744 \pm 0.046(1.40-2.00) \\
0.57 \pm 0.03(0.37-0.73)\end{array}$ & $\begin{array}{c}1.767 \pm 0.072 \\
0.65 \pm 0.03\end{array}$ & $\begin{array}{c}1.717 \pm 0.087 \\
0.49 \pm 0.06\end{array}$ \\
\hline $\begin{array}{l}\text { Total body } \\
\text { Lumbar spine } \\
\text { Femoral neck }\end{array}$ & $\begin{array}{l}88.6 \pm 1.4(77-97) \\
85.8 \pm 3.7(58-113) \\
81.9 \pm 2.0(65-93)\end{array}$ & $\begin{array}{l}89.5 \pm 2.2 \\
82.7 \pm 4.1 \\
79.0 \pm 2.8\end{array}$ & $\begin{array}{l}87.8 \pm 2.9 \\
92.2 \pm 9.8 \\
81.6 \pm 5.0\end{array}$ \\
\hline $\begin{array}{l}\text { BMD total body } \\
\% \text { of young adult } \\
\text { T-score }\end{array}$ & $\begin{array}{l}79.5 \pm 1.3(67-88) \\
-2.88 \pm 0.18(-4.63--1.68)\end{array}$ & $\begin{array}{c}81.3 \pm 1.8 \\
-2.62 \pm 0.26\end{array}$ & $\begin{array}{c}77.8 \pm 2.6 \\
-3.11 \pm 0.36\end{array}$ \\
\hline $\begin{array}{l}\text { S-IGF-I }(\mu \mathrm{g} / \mathrm{I}) \\
\text { S-IGF-I SD-score, age-matched } \\
\text { S-IGF-I-score, young adult } \\
\text { P-GH }(\mu \mathrm{g} / \mathrm{l}) \text { diurnal mean } \\
\text { P-GH }(\mu \mathrm{g} / \mathrm{l}) \text { max. diurnal peak } \\
\text { S-IGFBP-1 }(\mu \mathrm{g} / \mathrm{l}) \\
\text { S-IGFBP-3 }(\mu \mathrm{g} / \mathrm{l}) \\
\text { S-insulin }(\mathrm{pmol} / \mathrm{l}) \\
\text { B-glucose }(\mathrm{mmol} / \mathrm{l})\end{array}$ & $\begin{aligned} 121 & \pm 10(55-192) \\
-0.5 & \pm 0.3(-2.9-1.3) \\
-2.9 & \pm 0.3(-5.6--1.0) \\
0.6 & \pm 0.1(0.2-1.4) \\
5.5 & \pm 1.4(0.8-23.6) \\
42 & \pm 1(33-50) \\
2715 & \pm 162(1562-3745) \\
65 & \pm 6(33-125) \\
4.6 & \pm 0.1(3.8-5.5)\end{aligned}$ & $\begin{aligned} 136 & \pm 18 \\
-0.05 & \pm 0.5 \\
-2.5 & \pm 0.5 \\
0.7 & \pm 0.2 \\
4.2 & \pm 1.1 \\
41 & \pm 2 \\
2959 & \pm 222 \\
71 & \pm 13 \\
4.7 & \pm 0.2\end{aligned}$ & $\begin{aligned} 104 & \pm 18 \\
-1.1 & \pm 0.7 \\
-3.5 & \pm 0.7 \\
0.8 & \pm 0.05 \\
9.4 & \pm 3.6 \\
44 & \pm 2 \\
2449 & \pm 284 \\
47 & \pm 5 \\
4.4 & \pm 0.2\end{aligned}$ \\
\hline $\begin{array}{l}\text { S-osteocalcin }(\mu \mathrm{g} / \mathrm{l}) \\
\text { S-PICP }(\mu \mathrm{g} / \mathrm{l}) \\
\text { S-PIIINP (U/l) } \\
\text { S-ALP }(\mu \mathrm{kat} / \mathrm{l}) \\
\text { U-calcium }(\mathrm{mmol} / \mathrm{l}) \\
\text { U-hydroxyproline }(\mu \mathrm{mol} / \mathrm{l}) \\
\text { S-calcitriol }(\mathrm{ng} / \mathrm{l})\end{array}$ & $\begin{array}{c}24.7 \pm 1.6(17.0-39.0) \\
114 \pm 8(74-186) \\
794 \pm 32(520-1010) \\
3.1 \pm 0.1(2.0-3.8) \\
2.6 \pm 0.4(0.2-5.8) \\
111 \pm 22(19-360) \\
77 \pm 13(23-202)\end{array}$ & $\begin{array}{c}22.0 \pm 1.8 \\
107 \pm 13 \\
782 \pm 73 \\
3.2 \pm 0.2 \\
2.5 \pm 0.7 \\
96 \pm 28 \\
70 \pm 19\end{array}$ & $\begin{array}{c}24.8 \pm 2.5 \\
107 \pm 12 \\
798 \pm 28 \\
3.0 \pm 0.2 \\
3.2 \pm 0.9 \\
161 \pm 48 \\
49 \pm 9\end{array}$ \\
\hline $\begin{array}{l}\text { S-phosphate }(\mathrm{mmol} / \mathrm{l}) \\
\text { S-urea }(\mathrm{mmol} / \mathrm{l})\end{array}$ & $\begin{array}{l}1.2 \pm 0.03(0.9-1.5) \\
5.3 \pm 0.3(2.6-7.9)\end{array}$ & $\begin{array}{l}1.2 \pm 0.03 \\
5.8 \pm 0.5\end{array}$ & $\begin{array}{l}1.2 \pm 0.08 \\
4.4 \pm 0.5\end{array}$ \\
\hline
\end{tabular}

$\mathrm{S}$, serum; P, plasma; $\mathrm{B}$, blood; $\mathrm{U}$, urinary.

treated with $\mathrm{GH}$ from the beginning, GH/GH group. Before the start of the study no significant differences were observed between the two groups (Table 1).

Serum levels of IGF-I were within the mean \pm 2 s.D. value for age in 13 patients, and 3 were below -2 s.D., 2 of these also had subnormal IGFBP-3. Before GH treatment there was no statistically significant difference in the serum levels of IGF-I in the GH/GH group compared with the placebo/GH group, $104 \pm 18$ vs $144 \pm 15 \mu \mathrm{g} / \mathrm{l}$. Basal levels of IGF-I did not correlate with BMD, BMC or any other measured variable, except for negative correlations to markers for bone resorption: urine levels of calcium $(r=-0.607, P=0.013)$ and hydroxyproline $(r=-0.522, P=0.038)$. In contrast, a significant negative relation was found between baseline serum levels of IGFBP-1 and BMD in the femoral neck $(r=-0.610, P=0.012)$ as well as a positive relation to PICP $(r=0.550, P=0.027)$. No correlations were observed between BMI or body weight and any other variable, except for the expected positive correlation with LBM, BF and TBW.

The maximum peak $\mathrm{GH}$ was $5.5 \pm 1.4 \mu \mathrm{g} / \mathrm{l}$ during diurnal sampling. Serum concentrations of IGF-I, sampled in connection with the profiles, tended to be correlated negatively to the maximum diurnal peak values of $\mathrm{GH}(r=-0.472, P=0.076)$ and in addition they correlated well with the basal levels of IGF-I in this study $(r=0.860, P<0.001)$.

\section{Effects of GH on BMD and BMC}

In the 12 patients completing one year of GH therapy mean BMD in the total body and lumbar spine, as well as total body BMC, did not change during the treatment period, whereas a slight decrease $(3.4 \pm 1.6 \%)$ compared with basal values in femoral neck BMD was 
observed after 12 months $(P<0.05)$. This decrease was, however, due entirely to changes in the GH/GH group which had decreased levels of femoral neck BMD after 6 and 12 months $(P<0.05$ and $P<0.01$ respectively) (Fig. 1). In the patients belonging to the placebo/GH group no changes were found either during the placebo period or the GH treatment period.

Only four patients were followed for an additional year (i.e. for 2 years altogether) of active $\mathrm{GH}$ treatment. Mean BMD in the total body did not change, while BMD in the femoral neck returned to basal levels. Moreover, mean lumbar spine BMD increased $6.0 \pm 2.2 \%$ after 24 months compared with baseline $(P<0.01)$ in these patients (Fig. 1).

\section{Effects of GH on biochemical markers of bone metabolism}

When the groups were analysed separately, bone formation markers were found to have increased significantly in the GH/GH group (Fig. 2). Thus, serum concentrations of osteocalcin increased $88 \pm$ $21 \%(P<0.01)$ compared with baseline and reached maximum levels at 9 months, while PICP and PIIINP increased $36 \pm 11 \%(P<0.01)$ and $26 \pm 8 \%(P<0.01)$ respectively after 12 months. Mean values of total serum ALP, $3.1 \pm 0.1 \mu \mathrm{kat} / \mathrm{l}$ at baseline, did not change. During placebo treatment none of these variables was altered.

No statistically significant changes were found in the markers for bone resorption, urine hydroxyproline and calcium. Furthermore, no changes were found in serum levels of calcitriol.

\section{Effects of GH on LMB, TBW and BF}

A tendency towards improved mean values of LBM (from $36.8 \pm 1.1$ to $37.4 \pm 0.9 \mathrm{~kg})(P=0.072)$ was observed after one year of GH treatment when data from all patients were combined (Fig. 1). In the placebo/GH
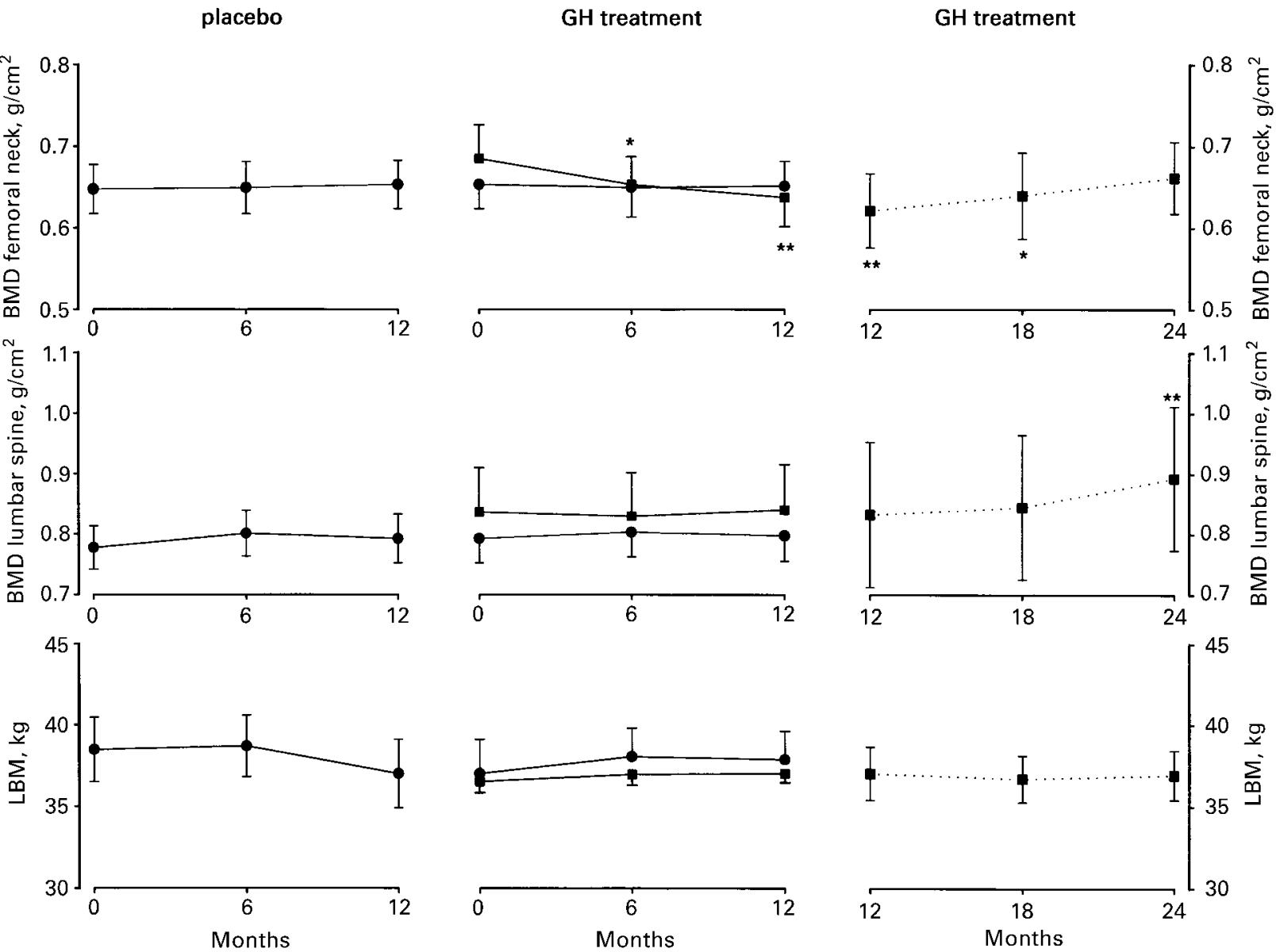

Figure 1 BMD in femoral neck, BMD in lumbar spine, and LBM in postmenopausal women with osteoporosis. Values are means \pm S.E.M. Left panels represent data from patients in the placebo/GH group $(\bullet, n=6)$ during the placebo period. Middle panels represent data from patients in the placebo/GH group $(\bullet, n=6)$ and patients in the $\mathrm{GH} / \mathrm{GH}$ group $(\boldsymbol{\square}, n=6)$ during the first year of GH treatment. Right panels represent data from patients in the $\mathrm{GH} / \mathrm{GH}$ group $(\boldsymbol{\square}, n=4)$ completing two years of $\mathrm{GH}$ treatment. ${ }^{\star} P<0.05$, ${ }^{\star *} P<0.01$ vs basal levels within group. 
group a tendency to declining levels of LBM was observed $(P=0.072)$ during the placebo period and after 12 months mean values were $96.1 \pm 1.4 \%$ compared with basal values. When comparing placebo vs $\mathrm{GH}$ treatment in the placebo/GH group using two factor ANOVA for repeated measures, no significant difference was found. Moreover, in the patients receiving $\mathrm{GH}$ therapy for two years no further changes were observed. Levels of TBW did not change due to $\mathrm{GH}$ treatment.

Mean levels of BF increased slightly after 12 months, from $23.5 \pm 2.1$ to $24.3 \pm 2.1 \mathrm{~kg}(P<0.05)$ when all patients were calculated together. During the placebo period, no changes were observed regarding TBW or BF. A slight weight gain was observed during $\mathrm{GH}$ treatment in the $\mathrm{GH} / \mathrm{GH}$ group, from $58.8 \pm 2.8 \mathrm{~kg}$ to $60.6 \pm 3.3 \mathrm{~kg}$ at 12 months $(P<0.05)$, whereas in the placebo/GH group no changes were found. The patients' heights did not alter significantly during either treatment.

\section{Effects of GH on IGF-I, IGFBP-3, IGFBP-1 and insulin}

After 12 months of GH therapy serum levels of IGF-I were increased in ten out of twelve patients, one patient had levels above +2 s.D., one had levels still below -2 s.D., while the majority remained within the normal range for age. The mean increase $(32 \pm 11 \mu \mathrm{g} / \mathrm{l})$ at 12 months was $32 \pm 12 \%$ of the basal level, ranging from -38 to $138 \%$. The increase over time was, however, significant only in the $\mathrm{GH} / \mathrm{GH}$ group, and could already be observed after one month's therapy $(P<0.05)$ and continued to increase in all six patients to $47 \pm 20 \%$ after 12 months $(P<0.01)$ (Fig. 3). In the placebo/GH group serum levels of IGF-I did not change significantly, either during the placebo period or during $\mathrm{GH}$ treatment. In the four patients who did not complete one year of $\mathrm{GH}$ therapy due to side effects, maximal increase in serum levels of IGF-I before cessation ranged from 35 to $114 \%$ (Fig. 3).
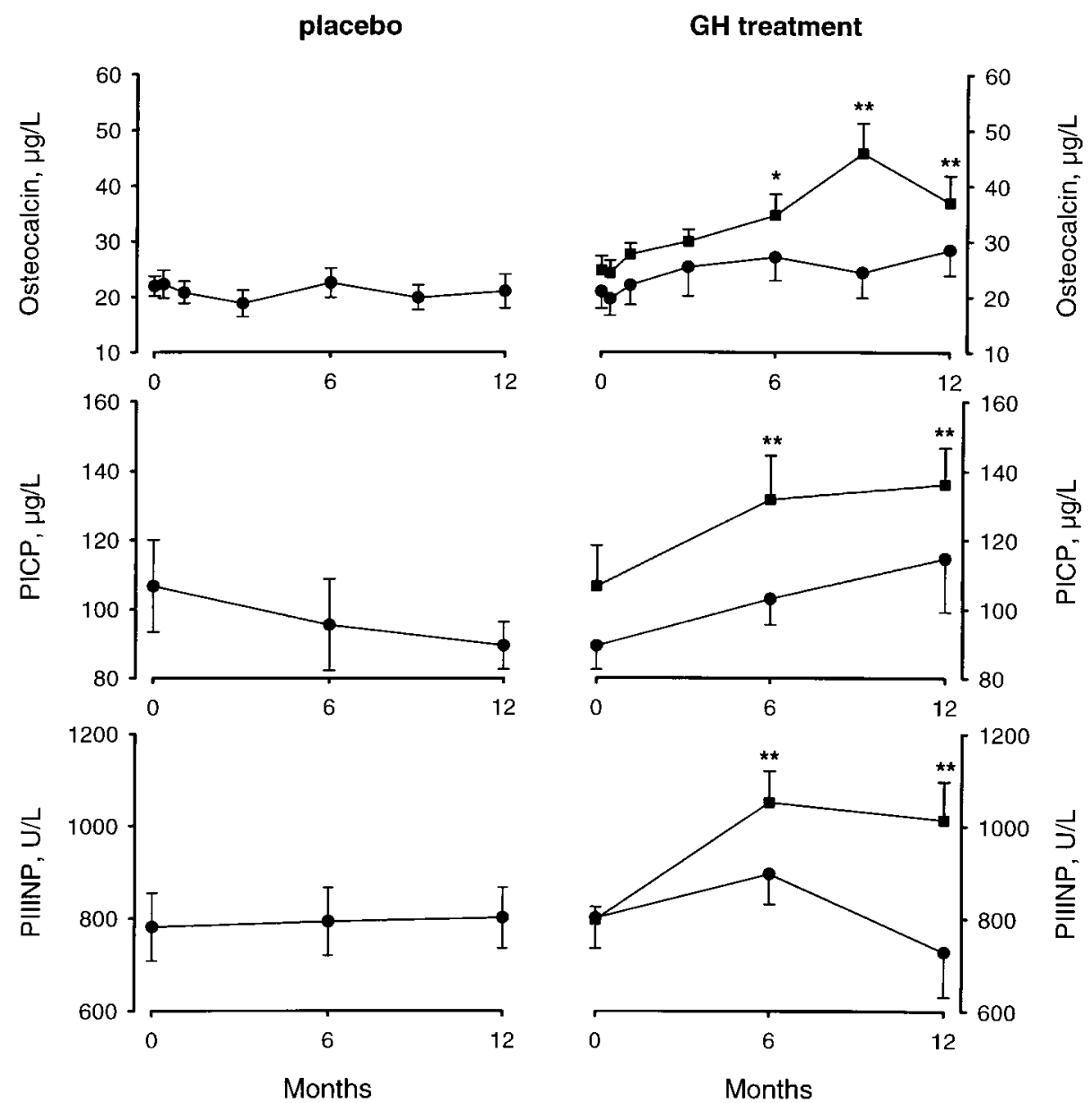

Figure 2 Serum levels of osteocalcin, PICP, and PIIINP (means \pm S.E.M.) in postmenopausal women with osteoporosis. Left panels represent data from patients in the placebo/GH group $(\bullet, n=6)$ during the placebo period. Right panels represent data from patients in the placebo/GH group $(\bullet, n=6)$ and patients in the $\mathrm{GH} / \mathrm{GH}$ group $(\boldsymbol{\square}, n=6)$ during the first year of $\mathrm{GH}$ treatment. ${ }^{\star} P<0.05$, ${ }^{* \star} P<0.01$ vs basal levels within group. 


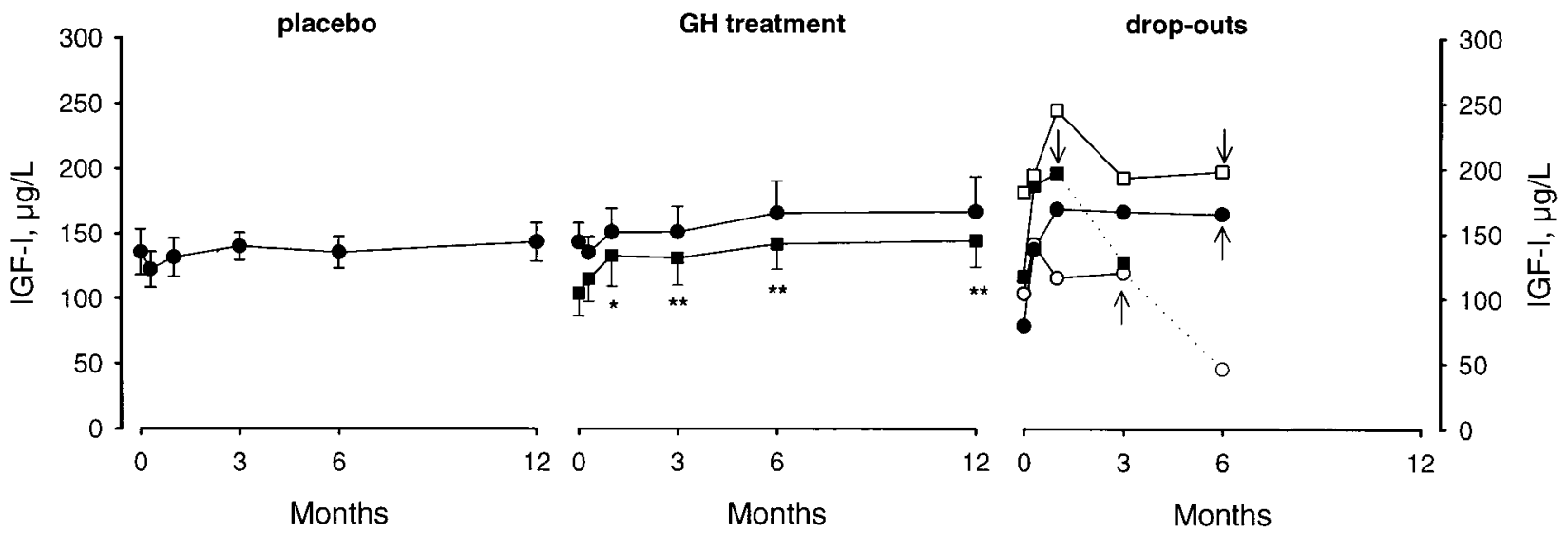

Figure 3 Serum levels of IGF-I (means \pm S.E.M.) in postmenopausal women with osteoporosis. Left panel represents data from patients in the placebo/GH group $(\bullet, n=6)$ during the placebo period. Middle panel represents data from patients in the placebo/GH group $(\bullet, n=6)$ and patients in the GH/GH group $(\mathbf{\square}, n=6)$ during the first year of $\mathrm{GH}$ treatment. Right panel represents individual values of IGF-I in the patients excluded from the study during the first year of $\mathrm{GH}$ treatment due to severe adverse effects. Arrows indicate the time point when $\mathrm{GH}$ therapy was discontinued. ${ }^{\star} P<0.05,{ }^{\star \star} P<0.01$ vs basal levels within group.

Also mean serum levels of IGFBP-3 increased significantly during GH treatment from $2759 \pm 224 \mu \mathrm{g} / \mathrm{l}$ before therapy to $3346 \pm 311 \mu \mathrm{g} / \mathrm{l}$ at 6 months $(P<0.01)$ and to $3253 \pm 254 \mu \mathrm{g} / \mathrm{l}(P<0.05)$ at 12 months, when both groups were calculated together. IGFBP-3 was not measured in samples collected during the placebo period.

Serum levels of IGFBP-1 did not change during placebo or GH therapy in either of the groups, when calculated separately or together. Unchanged serum levels of insulin were found in the placebo/GH group during both the placebo and the $\mathrm{GH}$ treatment period. However, a significant increase from $47 \pm 5 \mathrm{pmol} / \mathrm{l}$ to $75 \pm 11 \mathrm{pmol} / \mathrm{l} \quad(P<0.01)$ was observed after 12 months of GH treatment in the GH/GH group. Fasting blood glucose levels were unchanged during treatments and no difference was found between the two groups. Similarly, no changes were observed in serum levels of urea and phosphate (data not shown).

No relationships were found between either IGF-I or IGFBP-1 and variables for BMD, BMC, body composition or bone metabolism during $\mathrm{GH}$ treatment. Furthermore, changes in IGF-I did not correlate to changes in LBM or changes in osteocalcin, PICP and PIIINP.

\section{Changes in IGF-I in relation to GH dose and endogenous GH}

Serum IGF-I values or changes in serum IGF-I levels at 12 months did not correlate with the mean GH dose. Furthermore, levels or changes in IGF-I after 12 months GH therapy were not related to endogenous GH calculated as diurnal $\mathrm{GH}$ mean values or maximum peak values from the diurnal profiles of $\mathrm{GH}$. No relation was found between changes in IGF-I, calculated in absolute values or as a percentage, and basal levels of IGF-I, when data from all patients completing one year of GH treatment were compiled.

\section{Adverse effects during GH treatment}

Adverse events occurred in all patients during $\mathrm{GH}$ treatment, but only once during the placebo period. Most of these were expected side effects related to fluid retention as seen in GH-treated GHD patients. Four patients were excluded during the GH treatment period. The first patient developed carpal tunnel syndrome necessitating interruption of GH therapy after 3 months. Five weeks later she was excluded from the study due to the effect of cholestatic liver. The second patient was excluded after 6 months due to irreversible carpal tunnel syndrome symptoms requiring surgery. Two years after the study she developed similar problems in the other hand. The third patient was excluded due to a retinal vein thrombosis diagnosed after 5 weeks of $\mathrm{GH}$ treatment. The fourth patient stopped GH treatment after 4.5 months due to proximal thigh ache.

Five of the remaining twelve patients experienced mild and reversible stiffness and feelings of swollen fingers. One patient had similar complaints during the placebo period. Two further patients reported symptoms of carpal tunnel syndrome that disappeared slowly when the GH dose was decreased. One patient developed distinct trigger finger (tenosynovitis stenosans) that reversed with dose reduction. Four patients developed soft oedema of the lower legs and feet of various magnitude. In one case the oedema was pronounced and decreased slowly when the GH dose was decreased. Four patients developed swollen, aching knee regions. These symptoms persisted for several months in one patient despite GH dose reduction. Three further patients experienced symptoms of trochanteritis of moderate intensity. Three patients had temporary mild muscular tenderness. One of these patients developed thigh muscle weakness and visible atrophy of the 
quadriceps muscles, slowly normalising after ending GH treatment. One year after the study a seropositive rheumatoid arthritis was diagnosed in this patient.

During the two-year study period three symptomatic fractures took place, all during GH treatment. One of the patients fractured her patella and two patients had radiologically verified vertebral compression fractures. Several patients had more or less constant back pain for a long period before the study without any obvious deterioration during the study. In seven patients radiological findings of new or worsened vertebral body compression fractures were found.

\section{Discussion}

In the present group of postmenopausal women with manifest osteoporosis no beneficial effect on lumbar or total body bone mass or density (BMC or BMD) was observed with daily s.c. GH administered in mean doses between 0.5 and $2.7 \mathrm{U} /$ day for one year. Femoral neck BMD decreased slightly during the first year of $\mathrm{GH}$ treatment. Four patients, however, who continued GH treatment for a total of 24 months displayed a return of their femoral neck BMD to baseline and their lumbar BMD increased $6 \%$ above baseline levels. Whether their increased lumbar BMD indicates increased bone formation is uncertain since two of the patients treated for 24 months had progression of vertebral compressions within the lumbar spine region which might have contributed to the increased lumbar areal bone mass.

The initial decrease of BMD in our osteoporotic women resembles the effects observed in GHD patients, who lost bone during the first six months of $\mathrm{GH}$ treatment but reversed to a significant bone gain after more than one year of treatment (3). After three years of GH substitution the lumbar spine BMD of GHD patients had increased by $4.6 \%$ and the femoral neck BMD had increased by $7.1 \%$ (23). The bone mass of slightly osteopenic women did not change after one year of sequential GH treatment (13). After two years of therapy, however, significant increases were observed in total hip and lumbar spine (1.3 vs $1.7 \%$ ) but not in femoral neck. In contrast, Gonelli et al. (14) found a loss of bone mass in lumbar spine and femoral shaft after 2 years of sequential $\mathrm{GH}$ treatment in osteoporotic women. The differences between the results obtained might be explained by different levels of severity of osteoporosis, and/or variations in $\mathrm{GH}$ doses and regimes.

Nine of our twelve patients treated with $\mathrm{GH}$ for one year or longer had radiological progression of their vertebral compression fractures. This could be expected from the high risk of re-fractures in elderly women with manifest osteoporosis but it cannot be ruled out that $\mathrm{GH}$ treatment had a negative effect on bone connectivity and tenacity. It has been postulated that increased bone turn-over as such could cause an increased risk of fractures (24) possibly because of increased activation of bone remodelling units and the greater risk of bone perforations even when absolute loss of bone mass is small. Increased bone turnover might be more destructive in older individuals with a lower bone mass and greater risk of trabecular perforations and fractures.

In our osteoporotic patients there were small increases in the bone formation markers, serum osteocalcin and procollagen type I propeptide (PICP) while the relatively unspecific resorption markers, urine calcium and hydroxyproline, did not change significantly. Thus, bone turnover was affected, although marginally, indicating an effect of exogenous $\mathrm{GH}$ in the osteoporotic women in excess of their endogenous $\mathrm{GH}$ production. The bone formation and resorption markers in middle-aged GHD patients more than doubled following $\mathrm{GH}$ treatment in comparable doses $(2,3$, 25). Two- to tenfold higher $\mathrm{GH}$ doses $(0.2 \mathrm{U} / \mathrm{kg} /$ day $)$ for a short period ( 3 days) have been shown to induce an equally large bone marker response, unrelated to the serum IGF-I response, in osteoporotic and normal postmenopausal women $(26,27)$. Bone histomorphometric data indicated increased bone cell activation frequency and an increased formation period while the resorption period was shortened during $\mathrm{GH}$ treatment of young GHD males (28). Histomorphometric studies have not been reported in GH-treated postmenopausal women with osteoporosis.

No significant changes in LBM or TBW were found in the osteoporotic women after one year of GH treatment although a trend towards higher LBM was seen in comparison with a tendency to decrease during placebo treatment. The lack of significant effects on LBM and the tendency of body fat to increase is in contrast to the findings in GH-deficient patients $(29,30)$. Several reasons might have contributed such as low physical activity and increased awareness of adequate food intake in our elderly patients during the study period. Preliminary results indicate that fat mass does not decrease during GH therapy in elderly GHD patients although LBM increases (31). In healthy elderly males with IGF-I levels below the mean for age, slightly higher $\mathrm{GH}$ doses increased $\mathrm{LBM}(32,33)$. The $\mathrm{GH}$-induced increase in IGF-I was also much lower than the IGF-I response reported in GHD women treated with $\mathrm{GH}$ in the same dose range (30). In GHD patients we have observed that the GH-induced increase in LBM was correlated to the IGF-I increase (30). In growth retarded children the increase in growth velocity SD scores was found to be positively correlated to the increase in IGF-I and inversely correlated to pretreatment IGF-I levels (34).

A GH dose too low in relation to the endogenous $\mathrm{GH}$ production may be considered as a reason for the apparent GH resistance leading to a low IGF-I and LBM response in osteoporotic women compared with women with GHD. However, the many adverse events mostly attributed to water retention observed during $\mathrm{GH}$ therapy indicate that the amount of administered GH 
most likely exceeded the endogenous GH production. Furthermore, GH therapy resulted in a reduction in BMD, similar to that observed initially in GHD patients and attributed to a GH-induced increase of the remodelling space. Therefore, the discrepancy between multiple adverse effects of $\mathrm{GH}$ and the attenuated $\mathrm{GH}$ effects on IGF-I and LBM leads to the hypothesis that these osteoporotic women have a selective resistance to the GH-induced expression of IGF-I, which is assumed to mediate the anabolic effects of GH. The estrogendeficient state in our patients is unlikely to be the cause, since per oral oestrogen therapy decreases the GH-induced IGF-I response in GHD women. (35).

Failure of GH to induce an increase in IGF-I as well as growth and anabolism is well known during fasting and in malnourished patients such as those with anorexia nervosa (36). In lean healthy subjects fasting decreases the serum IGF-I levels in spite of increasing GH levels (37). Low serum IGFs and IGFBP-3 have been reported in women with postmenopausal osteoporosis (9). Although the participating women had a normal mean BMI of 24, we cannot exclude selective nutritional deficits. Low caloric intake and low protein content in the diet are usually accompanied by increased IGFBP-1 levels partly due to decreased insulin levels (38). In this context it is of interest that IGFBP-1 was the only variable displaying a significant and inverse correlation with BMD before GH therapy. Since circulating levels of free IGF-I have been shown to be inversely related to IGFBP-1 (39), the modulation of IGF-I bioavailability by IGFBP-1 is believed to be of importance for the anabolic action of $\mathrm{GH}$.

The role of cytokines in the pathogenesis of osteoporosis has been addressed in several studies during previous years. A prevalence of interleukin (IL)-1, IL- 6 and tumour necrosis factor- $\alpha$ mRNA has also been observed in bone biopsy samples from osteoporotic women (40). Whether increased cytokine production is a contributory cause of a selective $\mathrm{GH}$ resistance in our group of osteoporotic women is at present unknown.

In conclusion, the present placebo-controlled oneyear study does not support the use of $\mathrm{GH}$ for the treatment of elderly postmenopausal women with primary osteoporosis, who fail to respond with an increase in IGF-I. The finding of a possible selective GH resistance in our patient group needs to be confirmed in larger groups of patients. In osteoporotic women who respond with an increase in IGF-I, long term GH studies, perhaps with added bone resorption inhibitors, need to be performed to evaluate whether increased bone mass and fracture reduction can be established.

\section{Acknowledgements}

This study was supported by the Swedish Medical Research Council Grant nr 4224, Magn. Bergvall Foundation, Osterman Foundation and PharmaciaUpjohn Co. The authors are grateful to RN Anette
Härström for taking good care of the patients and IngaLena Wivall, Ella Wallerman and Berit Rydlander for skilful technical assistance.

\section{References}

1 de Muinck Keizer-Schrama SM, Rikken B, Wynne HJ, HokkenKoelega AC, Wit JM, Bot A et al. Dose-response study of biosynthetic hGH in GH-deficient children. Journal of Clinical Endocrinology and Metabolism 199274 898-905.

2 Degerblad M, Elgindy N, Hall K, Sjöberg HE \& Thorén M. Potent effect of recombinant growth hormone on bone mineral density and body composition in adults with panhypopituitarism. Acta Endocrinologica 1992126 387-393.

3 Degerblad M, Bengtsson BÅ, Bramnert M, Johnell J, Manhem P, Rosen $\mathrm{T}$ et al. Reduced bone mineral density in adults with growth hormone $(\mathrm{GH})$ deficiency: increased bone turnover during 12 months of GH substitution therapy. European Journal of Endocrinology $1995133180-188$.

4 Rosén T, Wilhelmsen L, Landin-Wilhelmsen K, Lappas G, Lindstedt G \& Bengtsson B- $\AA$. Increased fracture rate in growth hormone-deficient adults. 77th Annual Meeting of the Endocrine Society, Washington, DC 1997 Abstract P2-251.

5 Boonen S, Lesaffre E, Aerssens J, Pelemans W, Dequeker J \& Bouillon R. Deficiency of the growth hormone-insulin-like growth factor-I axis potentially involved in age-related alterations in body composition. Gerontology 199642 330-338.

6 Martin FC, Yeo A-L \& Sonksen PH. Growth hormone secretion in the elderly; ageing and the somatopause. Bailliere's Clinical Endocrinology and Metabolism 199711 223-250.

7 Wivall-Helleryd I-L, Hilding A, Höybye C, Melin A, Sääf M \& Thorén M. Serum levels of IGF-I in 448 healthy subjects aged 2096 years compared with IGF-I in 162 growth hormone-deficient patients aged 15-82 years. 4th International Symposium on Insulin-like Growth Factors, Tokyo 1997 Abstract A-29.

8 Ljunghall S, Johansson AG, Burman P, Kampe O, Lindh E \& Karlsson FA. Low plasma levels of insulin-like growth factor-I (IGF-I) in male patients with idiopathic osteoporosis. Journal of Internal Medicine 1992232 59-64.

9 Wüster CHR, Blum WF, Schlemilch S, Ranke M \& Ziegler R. Decreased serum levels of insulin-like growth factors-I and -II and IGF binding protein-3 in patients with osteoporosis. Journal of Internal Medicine 1993234 249-255.

10 Kurland ES, Rosen CJ, Cosman F, McMahon D, Chan F, Shane E et al. Insulin-like growth factor-I in men with idiopathic osteoporosis. Journal of Clinical Endocrinology and Metabolism 199782 2799-2805.

11 Johansson AG, Eriksen EF, Lindh E, Langdahl B, Blum WF, Lindahl A et al. Reduced serum levels of the growth hormone-dependent IGF binding protein and a negative bone balance at the level of individual remodeling units in idiopathic osteoporosis in men. Journal of Clinical Endocrinology and Metabolism 199782 27952798.

12 Aloia JF, Zanzi I, Ellis K, Jowsey J, Roginsky M, Wallach S et al. Effects of GH in osteoporosis. Journal of Clinical Endocrinology and Metabolism 197643 992-999.

13 Holloway L, Kohlmeier L, Kent K \& Marcus R. Skeletal effects of cyclic recombinant human growth hormone and salmon calcitonin in osteopenic postmenopausal women. Journal of Clinical Endocrinology and Metabolism 199782 1111-1117.

14 Gonelli S, Cepollaro C, Montomoli M, Gennari L, Montagnani A, Palmieri R et al. Treatment of post-menopausal osteoporosis with recombinant human growth hormone and salmon calcitonin: a placebo-controlled study. Clinical Endocrinology 199746 5561.

15 Kowarski A, Thompson RG, Migeon CJ \& Blizzars RM. Determination of integrated concentrations and the secretion rates of human growth hormone. Journal of Clinical Endocrinology and Metabolism 197132 356-360. 
16 Mazess RB, Barden HS, Bisek JP \& Hansson J. Dual energy X-ray absorptiometry for total body and regional bone-mineral and softtissue composition. American Journal of Clinical Nutrition 199051 1106-1112.

17 Christiansen C, Rodbro P \& Jensen H. Bone mineral content in the forearm measured by photon absorptiometry. Scandinavian Journal of Clinical and Laboratory Investigations 197535 323-330.

18 Bang P, Wivall I-L, Eriksson U, Sara V \& Hall K. Comparison of acid ethanol extraction and acid gel filtration prior to IGF-I and IGF-II radioimmunoassays: improvement of determinations in acid ethanol extracts by the use of truncated IGF-I as radioligand. Acta Endocrinologica 1991124 620-629.

19 Hilding A, Brismar K, Degerblad M, Thorén M \& Hall K. Altered relation between circulating levels of insulin-like growth factor binding protein-1 and insulin in growth hormone-deficient patients and insulin-dependent diabetic patients compared with that in healthy subjects. Journal of Clinical Endocrinology and Metabolism 199580 2646-2652.

20 Póvoa G, Roovete A \& Hall K. Cross-reaction of serum somatomedin-binding protein in a radioimmunoassay developed for somatomedin-binding protein isolated from human amniotic fluid. Acta Endocrinologica 1984107 563-570.

21 Hall K, Lundin G \& Póvoa G. Serum levels of low molecular weight form of insulin-like growth factor binding protein in healthy subjects and patients with growth hormone deficiency, acromegaly and anorexia nervosa. Acta Endocrinologica 1988118 321-326.

22 Paroni R, De Vecchi E, Fermo I, Arcelloni C, Domede L, Magni F et al. Total urinary hydroxyproline determined with rapid and simple high-performance liquid chromatography. Clinical Chemistry 1992 38 407-411.

23 Degerblad M, Bjellerup P, Brismar T \& Thorén M. Three years of growth hormone $(\mathrm{GH})$ replacement therapy in adults - increased and preserved bone mineral density. 10th International Congress of Endocrinology 1996 Abstract P3-47.

24 Garnero P, Sornay-Rendu E, Chaouy MC \& Delmas PD. Increased bone turnover in late postmenopausal women is a major determinant of osteoporosis. Journal of Bone and Mineral Research $199611337-346$.

25 Magnusson P, Degerblad M, Sääf M, Larsson L \& Thorén M. Different responses of bone alkaline phosphatase isoforms during recombinant insulin-like growth factor-I (IGF-I) and during growth hormone therapy in adults with growth hormone deficiency. Journal of Bone and Mineral Research 199712 210-220.

26 Kassem M, Brixen K, Blum WF, Mosekilde L \& Eriksen EF. Normal osteoclastic and osteoblastic response to exogenous $\mathrm{GH}$ in patients with postmenopausal osteoporosis. Journal of Bone and Mineral Research 19949 1365-1370.

27 Brixen K, Kassem M, Nielsen HK, Loft AG, Flyvbjerg A \& Mosekilde L. Short-term treatment with growth hormone stimulates osteoblastic and osteoclastic activity in osteopenic postmenopausal women: a dose-response study. Journal of Bone and Mineral Research $1995101865-1874$.

28 Bravenboer N, Holzmann P, de Boer H, Roos JC, van der Veen EA \& Lips P. The effect of growth hormone $(\mathrm{GH})$ on histomorphometric indices of bone structure and bone turnover in GH-deficient men. Journal of Clinical Endocrinology and Metabolism 1997821818 1822.
29 Johannsson G, Bjarnason R, Bramnert M, Carlsson LMS, Degerblad M, Manhem P et al. The individual responsiveness to growth hormone $(\mathrm{GH})$ treatment in GH-deficient adults is dependent on the level of GH-binding protein, body mass index, age and gender. Journal of Clinical Endocrinology and Metabolism 199681 1575-1581.

30 Thorén M, Hilding A, Baxter RC, Degerblad M, Wivall-Helleryd I-L \& Hall K. Serum insulin-like growth factor-I (IGF-I), IGF-binding protein-1 and -3, and the acid-labile subunit as serum markers of body composition during growth hormone $(\mathrm{GH})$ therapy in adults with GH deficiency. Journal of Clinical Endocrinology and Metabolism 199782 223-228.

31 Thorén M, Bramnert M, Hilding A, Backman C, Castenfors J, Johansson BL et al. Elderly patients with pituitary insufficiency benefit from growth hormone replacement therapy. 80th Annual Meeting of the Endocrine Society, New Orleans 1998 Abstract, pp 1-199.

32 Rudman D, Feller A, Nagraj H, Gergans GA, Lalitha PY, Goldberg AF et al. Effects of human growth hormone in men over 60 years old. New England Journal of Medicine 1990323 1-6.

33 Marcus R, Butterfield G, Holloway L, Gilliland L, Baylink DJ, Hintz RL et al. Effects of short term administration of recombinant human insulin-like growth hormone to elderly people. Journal of Clinical Endocrinology and Metabolism 199070 519-527.

34 Kriström B, Jansson C, Rosberg S \& Albertsson-Wikland. Growth response to growth hormone $(\mathrm{GH})$ treatment relates to serum insulin-like growth factor-I (IGF-I) and IGF binding protein-3 in short children with various GH secretion capacities. Journal of Clinical Endocrinology and Metabolism 199782 2889-2903.

35 Weissberger AJ, Ho KY \& Lazarus L. Contrasting effects of oral and transdermal routes of estrogen replacement therapy on 24-h growth hormone $(\mathrm{GH})$ secretion, insulin-like growth factor-I and GH-binding protein in postmenopausal women. Journal of Clinical Endocrinology and Metabolism 199172 374-381.

36 Argente J, Caballo N, Barrios V, Munoz MT, Pozo J, Chowen JA et al. Multiple endocrine abnormalities of the growth hormone and insulin-like growth factor axis in patients with anorexia nervosa: effect of short- and long-term weight recuperation. Journal of Clinical Endocrinology and Metabolism 199782 20842092.

37 Bang P, Brismar K, Rosenfeld RG \& Hall K. Fasting affects serum insulin-like growth factors (IGFs) and IGF binding proteins differently in patients with NIDDM versus healthy non-obese and obese, weight matched subjects. Journal of Clinical Endocrinology and Metabolism 199478 960-967.

38 Sara VR \& Hall K. The insulin-like growth factors and their binding proteins. Physiological Reviews 199070 591-614.

39 Frystyk J, Vestboe E, Skjaerbeck C, Mogensen CE \& Orskov H. Free insulin-like growth factors in human obesity. Metabolism 199544 37-44.

40 Ralston SH. Analysis of gene expression in human bone biopsies by polymerase chain reaction: evidence for enhanced cytokine expression in postmenopausal osteoporosis. Journal of Bone and Mineral Research $19949883-890$.

Received 2 October 1998

Accepted 21 January 1999 